\title{
Assessing Malaysian Teachers' Perception on Computational Thinking Concepts Using SEM
}

Ung, L. Ling, Tammie, C. Saibin, Jane, Labadin, and Norazila, Abdul Aziz

\begin{abstract}
Computational thinking (CT) concepts are newly introduced concepts in the Malaysian curriculum. This study is therefore designed to investigate Malaysian teachers' perception on the integration of computational thinking skills in their teaching and learning practices. A survey form was designed based on the Technological Acceptance Model (TAM) and was disseminated throughout Malaysia to gauge teachers' perception on CT based on the perceived usefulness of $\mathrm{CT}$, perceived ease of $\mathrm{CT}$ integration into teaching and learning practices, teachers' attitude towards CT and their intention to use CT in their classrooms. A total of 166 primary school teachers participated in the survey and the data was analysed using Structural Equation Modelling (SEM). This study managed to predict Malaysian teachers' intention in integrating computational thinking skills in their classroom practices via two significant determinants, namely the perceived ease of integration and positive attitude towards computational thinking. This study is important because it highlights factors affecting teachers' perception on the newly improvised curriculum, and is an effort to support CT delivery in Malaysian classrooms.
\end{abstract}

Keywords: computational thinking . Technological Acceptance Model (TAM) · primary school teachers ' perception · Structural Equation Modeling (SEM) ·

Ung Ling Ling $\square \cdot$ Tammie, C. Saibin

Faculty of Computer and Mathematical Sciences, University Teknologi MARA

(UiTM), 88999 Kota Kinabalu, Sabah, Malaysia

e-mail: ungli720@sabah.uitm.edu.my

Tammie C. Saibin

e-mail: tammi023@sabah.uitm.edu.my

Jane Labadin . Norazila Abdul Aziz

Institute of Social Informatics and Technological Innovations (ISITI), Universiti Malaysia Sarawak (UNIMAS), 94300 Kota Samarahan, Sarawak, Malaysia

e-mail : ljane@unimas.my

Norazila Abdul Aziz

e-mail: anora@unimas.my 